\title{
The Effect of Budget Deficit on the Economy of Jordan
}

\author{
KHALED ABDALLA MOH'D AL-TAMIMI \\ Department of Financial and Administrative Sciences \\ Irbid University College, Al-Balqa' Applied University, \\ Irbid \\ JORDAN
}

\begin{abstract}
This paper describes the impact of budget deficit on the Jordanian economy for the period (2010 2019) where budget deficit and inflation are explanatory variables and economic growth is the affected variable. This research concentrates on analyzing theoretical and empirical literature reviews to show the effects of budget deficit on economic growth and explaining this effect for this period using the Autoregressive distributed lag (ARDL) method in Eviews program. The results of this research show that budget deficit calculated as a percentage of GDP and inflation rate have insignificant effects on the Jordanian economy for the period $(2010$ - 2019). This paper concludes with a recommendation that, apart from budget deficit and inflation rate, other variables that affect the economy exist.
\end{abstract}

Key-words:- Budget deficit, Economy of Jordan, Inflation, Economic growth, Autoregressive distributed lag (ARDL).

Received: March 27, 2020. Revised: August 6, 2020. Re-Revised: August 12, 2020. Accepted: August 18, 2020. Published: August 25, 2020.

\section{Introduction}

Budget deficit happens when government expenditures exceed revenues. There is a debate about the effect of budget deficit on economic growth in developed and developing states in recent years in the theoretical and empirical literature [1].Budget deficit is not always a negative indicator of the health of an economy. The negative impact of fiscal deficit on the economy happens when there is a shortage in governments' resources for meeting their expenditures in the long- term [2].The impacts of fiscal deficit on the economy are explained by a lot of economists. According to Keynesians, there is a positive relationship between fiscal deficit and the economy, while classical researchers see that there is a negative relationship between fiscal deficit and the economy and Ricardian researchers believe that there is no relationship between fiscal deficit and the economy [3].This research explains the effect of budget deficit on the Jordanian economy for the period (2010 - 2019), by determining literature reviews of the effects of budget deficit on the economy, and estimating the effect of budget deficit on Jordan's economy for the period $(2010-2019)$ by using the autoregressive distributed lag (ARDL) method in Eviews program as follows:

\section{Research questions}

The basic question of the research is: what is the effect of budget deficit on the economy of Jordan for the period $(2010-2019)$ ?Other questions that may arise from the basic question include:

1. What are the theoretical and empirical literature reviews that explain the impact of budget deficit on the economy?

2. What is the slope of a budget deficit curve for Jordan for the period $(2010-2019)$ ?

3. What is the slope of the curve for Jordan's economy for the period $(2010-2019)$ ?

\section{Research aims}

The basic aim of the research is to test the effect of budget deficit on the Jordanian economy for the period $(2010-2019)$. Other aims that may arise include:

1. Explaining theoretical and empirical literature reviews that explore the effect of budget deficit on the economy.

2. Knowing the slope of a budget deficit curve for Jordan for the period (2010 2019).

3. Determining the slope of the curve for Jordanian economy for the period (2010 2019). 


\section{Research hypothesis}

The basic hypothesis of the research is there is a negative impact of budget deficit on the economy of Jordan for the period (2010 - 2019).

\section{Literature review}

Fiscal deficit effect on the economy is as follows:

There is a negative impact of fiscal deficit on the economy by various channels as it increases the percentage of debt-to-GDP ratio which negatively affects the fiscal sustainability of the government. States rely on taxes and earnings from trade for mobilization of revenues. Mobilization of revenues has been insufficient in several years and these countries depend on earnings from trade and tariffs which have volatility. So revenue shortages and expenditures excess are one of the most common features of the countries [4] \&[5]. Economists of the Keynesian, Classical, and Ricardian thoughts have analyzed the fiscal deficit impact on the economy. They have explained the fiscal policy role from various angles. The Classical school uses the mechanism of markets for working. So, the mechanism of price works in the case of the existing efficient hypothesis of markets with the allocation of resources that are independent and efficient without the intervention of the government. The problem with this school is market failure evidence that led to the Great Depression of the 1930s. The Classical school expresses a negative effect of fiscal policy on economic growth. The school assumed that in the case of financing government expenditure by taxes, this will result in rising fiscal deficits that increase consumption. This will decrease savings and increase rates of interest for the capital market to be in an equilibrium case, and this decreases investment and economic growth [4] \&[6]. The Keynesian school which followed Keynes suggests the multiplier effect of activities of the government. The school viewed that fiscal deficit leads to an increase in domestic production as a result of increasing public capital expenditures on infrastructures like airports, water, power, and roads coupled with private investors' optimism for the future, and thus leading to increasing investments. So, the impacts of unemployment, inflation, and population were as a result of the failure of the government in intervening with economic policies. The school had an advocation of government's participation that will encourage the involvement of the private sector and this increases economic growth in the long and short terms [7] $\&[8]$. The Ricardian school viewed that governments work in a closed economy and public expenditure has no impact on taxes in these governments. In the case of lowering fiscal deficits, there is an increase in the desired private savings levels which do not affect national savings as well as real interest rates. A deficit that is financed by taxes has no impact on the real exchange rate and trade balance. There is no impact on public debt and investment because interest rates do not increase to reach investment and national savings balance. So, fiscal policy does not affect investment because there is no effect of taxes on consumption. After all, people have a view of assessing the present value of a savings balance in relation to the increase in future taxes [4] \& [9].

At the end of the theoretical and empirical literature, the researcher can refer to the negative or insignificant impact of a budget deficit because it leads to a decrease or no effect on the economic growth of Jordan.

\section{Fiscal deficit impact on Jordanian economy for the period (2009-2019)}

\subsection{Method}

The research covers the period from $(2010-2019)$ of the Jordanian budget deficit and the economic growth variables. The next equation represents the budget deficit effect on the Jordanian economy.

$$
\begin{aligned}
& \text { Economic growth } \\
& \qquad=f(\text { budget deficit, inflation })
\end{aligned}
$$

\subsection{Result}

This part explains Jordan's budget deficit and the growth of the economy variables for the period of $(2010-2019)$. 


\subsubsection{Jordan's budget deficit}

Table 1 Budget deficit percentage of GDP of Jordan for the period $(2010-2019)$

\begin{tabular}{|c|c|}
\hline Year & $\begin{array}{c}\text { Budget deficit percentage of GDP of } \\
\text { Jordan }\end{array}$ \\
\hline $2009 / 2010$ & 5.6 \\
\hline $2010 / 2011$ & 6.8 \\
\hline $2011 / 2012$ & 8.3 \\
\hline $2012 / 2013$ & 5.5 \\
\hline $2013 / 2014$ & 2.3 \\
\hline $2014 / 2015$ & 3.4 \\
\hline $2015 / 2016$ & 3.2 \\
\hline $2016 / 2017$ & 2.6 \\
\hline $2017 / 2018$ & 2.4 \\
\hline $2018 / 2019$ & 3.4 \\
\hline
\end{tabular}

Source: prepared by a researcher using Trading Economics statistics

Fig.1. budget deficit percentage to GDP of Jordan for the period $(2010-2019)$

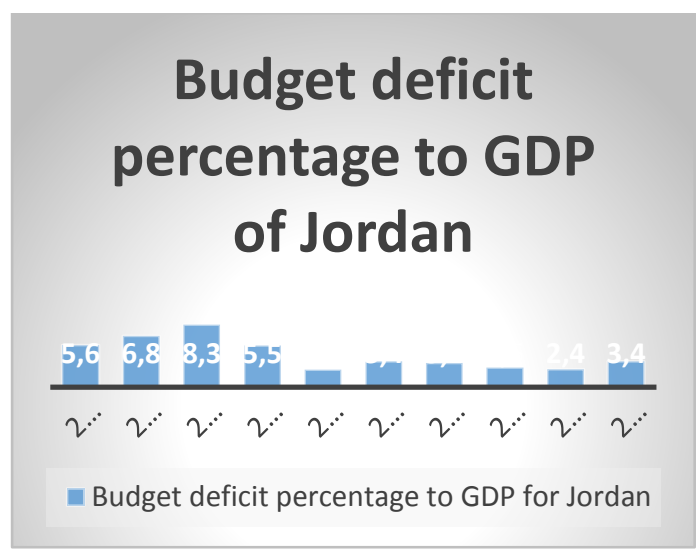

Source: prepared by a researcher using Trading Economics statistics

Table 1 and Fig. 1 show a fluctuation in budget deficit percentage of GDP for Jordan for the period $(2010$ - 2019). It increased in the first three months, where it reached $8.3 \%$ in 2011/2012. After that, it decreased to $2.4 \%$ in $2017 / 2018$. Then, it increased to $3.4 \%$ in $2018 / 2019$.

\subsubsection{Inflation rate in Jordan}

Table 2 Inflation rate in Jordan for the period (2010 -2019)

\begin{tabular}{|c|c|}
\hline Year & $\begin{array}{c}\text { Inflation rate } \\
\text { in Jordan }\end{array}$ \\
\hline $2009 / 2010$ & 4.8 \\
\hline $2010 / 2011$ & 4.2 \\
\hline $2011 / 2012$ & 4.5 \\
\hline $2012 / 2013$ & 4.8 \\
\hline $2013 / 2014$ & 2.9 \\
\hline $2014 / 2015$ & -0.9 \\
\hline $2015 / 2016$ & -0.8 \\
\hline $2016 / 2017$ & 3.3 \\
\hline $2017 / 2018$ & 4.5 \\
\hline $2018 / 2019$ & 0.8 \\
\hline
\end{tabular}

Source: prepared by a researcher using Trading Economics statistics

Fig.2 Inflation rate in Jordan for the period (2010 2019)

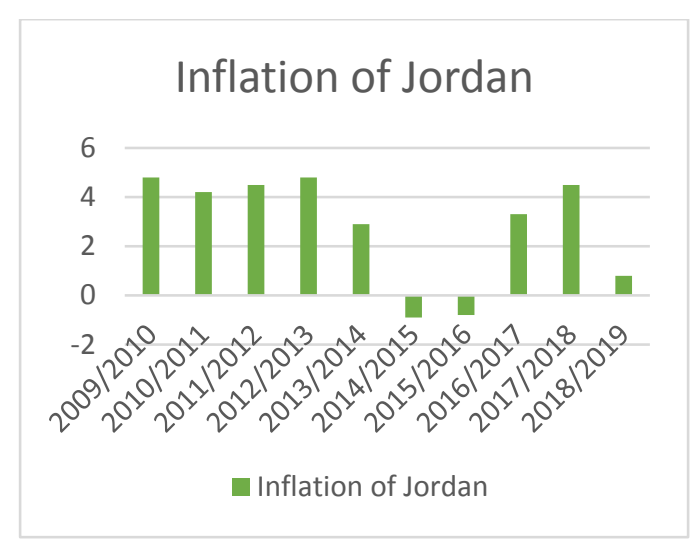

Source: prepared by a researcher using World Bank statistics

Table 2 and Fig. 2 reflect a fluctuation in the inflation rate in Jordan for the period (2010 2019). There was no inflation in $2014 / 2015$ and $2015 / 2016$, but there was an increase in it in $2016 / 2017$ and $2017 / 2018$. Then, there was a decrease in it in 2018/2019.

\subsubsection{Jordan's economic growth}

Table 3 Economic growth of Jordan for the period (2010 - 2019)

\begin{tabular}{|c|c|}
\hline Year & $\begin{array}{c}\text { Economic growth of } \\
\text { Jordan }\end{array}$ \\
\hline $2009 / 2010$ & 2.3 \\
\hline $2010 / 2011$ & 2.6 \\
\hline $2011 / 2012$ & 2.7 \\
\hline
\end{tabular}




\begin{tabular}{|c|c|}
\hline $2012 / 2013$ & 2.8 \\
\hline $2013 / 2014$ & 3.1 \\
\hline $2014 / 2015$ & 2.4 \\
\hline $2015 / 2016$ & 2 \\
\hline $2016 / 2017$ & 2.1 \\
\hline $2017 / 2018$ & 1.9 \\
\hline $2018 / 2019$ & 3.4 \\
\hline
\end{tabular}

Source: prepared by a researcher using World Bank statistics

Fig.3 Jordan's economic growth for the period $(2010-2019)$



Source: prepared by a researcher using World Bank statistics

Table 3 and Fig. 3 show a fluctuation in the economic growth of Jordan for the period (2010 2019). It reached $3.1 \%$ in $2013 / 2014$, then it decreased to $1.9 \%$ in $2017 / 2019$. Once again, there was an increase in it in the later part of 2018/2019 where it reached $3.4 \%$.

\section{Discussion}

The following table and figure show the budget deficit impact on the Jordanian economy for the period $(2010-2019)$.

Table 4 Budget deficit percentage of GDP, inflation rate, and economic growth of Jordan for the period (2010 - 2019)

\begin{tabular}{|c|c|c|c|}
\hline Year & $\begin{array}{c}\text { Budget } \\
\text { deficit } \\
\text { percentage } \\
\text { of GDP of } \\
\text { Jordan }\end{array}$ & $\begin{array}{c}\text { Inflation } \\
\text { in } \\
\text { Jordan }\end{array}$ & $\begin{array}{c}\text { Economic } \\
\text { growth of } \\
\text { Jordan }\end{array}$ \\
\hline $2009 / 2010$ & 5.6 & 4.8 & 2.3 \\
\hline $2010 / 2011$ & 6.8 & 4.2 & 2.6 \\
\hline $2011 / 2012$ & 8.3 & 4.5 & 2.7 \\
\hline $2012 / 2013$ & 5.5 & 4.8 & 2.8 \\
\hline
\end{tabular}

\begin{tabular}{|c|c|c|c|}
\hline $2013 / 2014$ & 2.3 & 2.9 & 3.1 \\
\hline $2014 / 2015$ & 3.4 & -0.9 & 2.4 \\
\hline $2015 / 2016$ & 3.2 & -0.8 & 2 \\
\hline $2016 / 2017$ & 2.6 & 3.3 & 2.1 \\
\hline $2017 / 2018$ & 2.4 & 4.5 & 1.9 \\
\hline $2018 / 2019$ & 3.4 & 0.8 & 3.4 \\
\hline
\end{tabular}

Source: prepared by a researcher using World Bank statistics

Fig.4 Budget deficit percentage of GDP, inflation rate and economic growth of Jordan for the period $(2010-2019)$

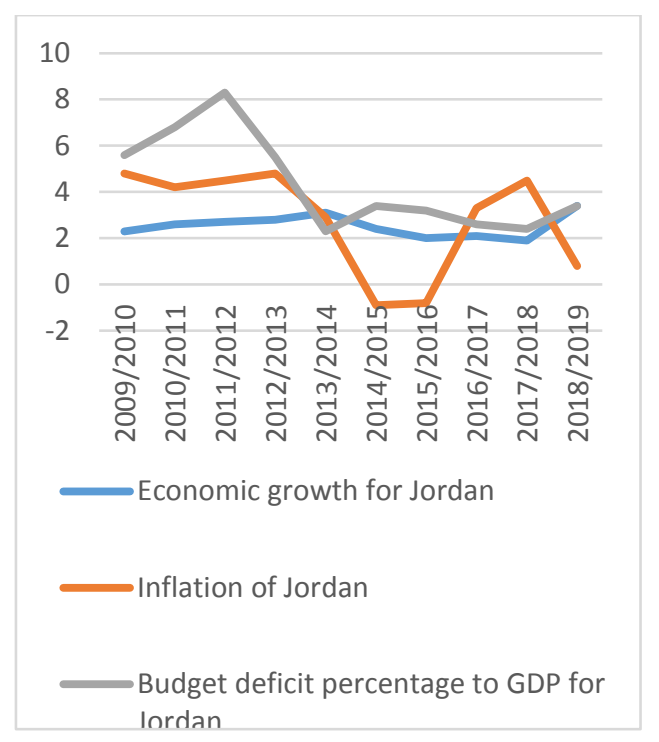

Source: prepared by a researcher using World Bank and Trading Economics data

Table 4 and Fig. 4 show an effect of fiscal deficit on the Jordanian economy for the period (2010 2019), Also, an insignificant effect of fiscal deficit on the Jordanian economy was shown.

For the verification of this effect, this research used the Autoregressive distributive lag (ARDL) method to test the effect of budget deficit on the economic growth of Jordan for the period $(2010-2019)$ 


\begin{tabular}{lccc}
\multicolumn{5}{c}{$\begin{array}{c}\text { Dependent Variable: GROWTH } \\
\text { Method: ARDL }\end{array}$} \\
Date: 07/01/20 Time: $18: 31$ \\
Sample (adjusted): 2011 2019 \\
Included observations: 9 after adjustments \\
Dependent lags: 1 (Fixed)
\end{tabular}

The above table shows insignificant effects of budget deficit percentage of GDP and inflation rate on the Jordanian economy for the period (2010 2019 ) at a level of significance $5 \%$.

\section{Conclusion and recommendation}

The research estimates the budget deficit effect on economic growth in the theoretical and empirical literature reviews, and fiscal deficit effect on the Jordanian economy, by employing the autoregressive distributed lag (ARDL) for the period $(2010$ - 2019). This research reports insignificant effects of budget deficit percentage of GDP and inflation rate on the economic growth of Jordan for the period $(2010$ - 2019) at the level of significance 5\%. This paper concludes with a recommendation that apart from budget deficit and inflation rate, other variables such as investments affect the economy.

\section{References}

[1] Tung, L. T.(2018). "The Effect of Fiscal Deficit on Economic Growth in an Emerging Economy: Evidence from Vietnam", Journal of International Studies, Vol.11,No.3,pp.191203.URL:

https://www.jois.eu/files/16 497 Tung.pdf

[2] Ahmad, F. \& Rahman, B. (2017). "The Relationship between Budget Deficit and Economic Growth: A Study on Bangladesh ASA University Review, Vol. 11, No. 2, July December, $\quad$ pp. $\quad 1 \quad-14$. URL:https://www.researchgate.net/publication/326 689582 The Relationship between Budget Defic it_and_Economic_Growth_A_Study_on_Banglade sh? enrichId=rgreq3b6b02b7cfc430f1d5d269ee336b d972XXX\&enrichSource=Y292ZXJQYWdlOzMy
NjY4OTU4MjtBUzo2NTQ0NTMxMTE3ODc1Mz RAMTUzMzA0NTE4OTgxNQ\%3D\%3D\&el=1_x 2\&_esc=publicationCoverPdf

[3] Hussain, M. \& Haque, M. (2017). "Fiscal Deficit and Its Impact on Economic Growth: Evidence from Bangladesh", Economic Research Forum, Policy Brief Economies, Vol. 5,No.37.URL:http://www.businessinsider.com/ban gladesh-is-the-new-asian-tiger-2017-4

[4] Gyasi, G. (2020). "The Impact of Fiscal Deficit on Economic Growth: Using the Bounds Test Approach in the Case of Morocco", United Nations Economic Commission For Africa, University of Energy and Natural Resources, Sunyani, Ghana, March, No. 98925. URL: https://mpra.ub.unimuenchen.de/98925/

[5] Futagami, K. \& Shibata, A. (2003). "Budget Deficits and Economic Growth", Center for Intergenerational Studies, Institute of Economic Research, Hitotsubashi University, January, Discussion Paper No. 133

URL:https://ideas.repec.org/p/hit/piedp1/133.html

[6] Van,V. \& Sudhipongpracha, T. (2015). "Exploring Government Budget Deficit and Economic Growth: Evidence from Vietnam's Economic Miracle", Asian Affairs: An American Review, Vol. 42, No. 3 , pp. 127 - 148 . URL: https://www.tandfonline.com/doi/full/10.1080/0092 7678.2015.1048629? scroll=top\&needAccess $=$ true

[7] Ezzat, A. \& Hosni, R. (2018). "Budget Deficit Volatility, Institutional Quality and Macroeconomic Performance", Faculty of Economics and Political Science,Cairo University, Egypt, Vol. 12, No. 2, pp. 21 40.URL:https://emuni.si/wpcontent/uploads/2020/0 1/IJEMS-2-2019_21-40.pdf

[8] Molocwa, G., Khamfula, Y. \& Cheteni, P. (2018). "Budget deficits, investment and economic growth: a panel cointegration approach", Investment Management and Financial Innovations, Vol. 15, No. 3, pp. 182 189.URL:https://businessperspectives.org/images/p df/applications/publishing/templates/article/assets/1 0816/imfi 201803 Molocwa.pdf

[9] Brender, A. \& Drazen, A. (2008). "How Do Budget Deficits and Economic Growth Affect Reelection Prospects? Evidence from a Large Panel of Countries",The American Economic Review,Vol.98,No.5,December,pp.22032220.URL:hhttps://www.jstor.org/stable/29730168 ?seq $=1$ 


\section{Creative Commons Attribution}

\section{License 4.0 (Attribution 4.0}

International , CC BY 4.0)

This article is published under the terms of the Creative Commons Attribution License 4.0

https://creativecommons.org/licenses/by/4.0/deed.e n US 